\title{
Loyal Dissent in the Chinese Blogosphere: Sina Weibo Discourse on the Chinese Communist Party
}

\author{
Johan Lagerkvist \& Gustav Sundqvist \\ Swedish Institute of International Affairs, Stockholm University, Sweden \\ Correspondence: Johan Lagerkvist, Swedish Institute of International Affairs, Stockholm University, Sweden. \\ E-mail: johan.lagerkvist@ui.se
}

Received: April 10, 2013 Accepted: April 24, 2013 Available online: May 3, 2013

doi:10.11114/smc.v1i1.121 URL: http://dx.doi.org/10.11114/smc.v1i1.121

\begin{abstract}
The impact of the Internet on Chinese politics is a hot topic in contemporary academic debate. Some scholars believe that political discussions in cyberspace will lead to a more pluralistic and democratic China. Others argue that the ruling Communist Party will strengthen its position by using the Internet as a tool for censorship and active propaganda. The purpose of this article is to contribute to the debate on the political impact of increasing Internet use, by studying uncensored online opinions about the Communist Party and its policies. More specifically, we investigate and analyze some of the most popular and uncensored microblog tweets (Sina Weibo) that discussed political scandals in China during the Spring of 2012. The findings show that a majority of the tweets contains criticism against certain activities of the Party, but do not challenge its hold on power. The study indicates that the phenomenon of loyal dissent is a distinguishing feature of online political discourse in contemporary China. Consequently, the blogosphere has the potential to foster a generation of more critical Chinese citizens. However, in the current phase of overall information repression and censorship, and as a particular form of online expression, microblogging cannot yet be considered a catalyst for democratization.
\end{abstract}

Keywords: Internet, China, censorship, Sina, Weibo, microblogging, CCP, loyal dissent, blogosphere, civil society

\section{Introduction}

With 580 million users (2012) and an estimated 650 million users by 2015, China's Internet population is already the world's largest. Many of these are active bloggers (329 million in 2009). Chinese blogs, and in particular the Chinese microblogs, weibo (微博), have since their beginning in 2009 become very popular and Although Chinese users mostly use the Internet as a tool for amusement and social networking, political activism is also growing (Yang, 2009, p.25). However, this trend notwithstanding, China's Communist Party (CCP) is intent to firmly control the Chinese media system and online public opinion, while the People's Republic continue to engage with the outside world economically, culturally and socially. The tension between a closely monitored media system and citizen's online discourse and generally sense of increasing personal freedoms and openness online make the impact of intense internet usage highly topical for both media studies and the discipline of political science. This article contributes to debates within both research fields. Relatively uncensored online discussions on Chinese politics in recent years have picked up speed in recent years, alongside the breaking of many scandals concerning corrupt and immoral behavior among China's political and economic elites. Arguably, these discussions have a particular huge influence on political discourse since they have been quite accessible and drawn a lot of interest among Chinese Internet users. The purpose of this study is to analyze and explain the implications of several scandals and sensitive events of 2012. In order to reach a deeper understanding of the online debate concerning this event, we investigate Chinese microbloggers' descriptions of how the CCP handled sensitive political issues during the spring of 2012 are investigated. According to the study, a majority of the tweets express loyal dissent toward the CCP by criticizing the party's policies without directly challenging its leadership or the existing political system at large. The study's results demonstrate the usefulness of the concept "loyal dissent" as a tool for analyzing Chinese politics also in the Internet age. The concept is not only suitable for analyzing the protest movement on China's countryside (Lagerkvist, 2012) but can also be used for analyzing political discussions in the Chinese blogosphere. The findings support the arguments of observers 
who argue that even if increasing Internet use may incite changes and perhaps improvements to China's political system, it will not necessarily contribute to regime change or a system overhaul soon.

\section{The Research Field}

The views on the future implications of Internet usage on China's political system and its future can roughly be categorized into three major schools of thought (Note 1). First, there are the "optimists" who believe that the Internet eventually will tear down the so-called Great Firewall of China that currently surrounds it. Moreover, they hold that China's one-party system will be replaced it with a more democratic political system. Second, there are the "skeptics." In contrast to the views of the former school, the skeptics argue that the CCP will be able to maintain its power by using Internet as a tool of political control. In between these opposites we find a third school of thought, the "reserved optimists." Although many of these acknowledge that growing Internet use certainly strengthen activists, including those who try to change the party's structure, behavior and policies, they don't anticipate a breakdown of the current one-party system. In this article, categories based on these three schools are used in order to analyze the political content in popular and uncensored microblog tweets. The study's findings support the standpoint of the "reserved optimists" insofar that loyal dissent is a very common phenomenon in online political discussions in the People's Republic.

\subsection{Optimists}

A considerable number of observers and China watchers who discuss the political impact of increasing Internet use can be described as optimists. One of the most famous is the Nobel Peace Prize winner Liu Xiaobo. In 2006, he declared that: "the Internet is God's great gift to China - it has provided the Chinese people with the best tool in their efforts to cast off slavery and fight for freedom" (Schola, 2010). Liu's view is partly shared by scholars who argue that Internet strengthen the Chinese people at the expense of the Chinese government (Xiao, 2004) and thus forge the foundation for a democratic system (Yang, 2009, p. 214). Some optimists have expressed significant doubt that China's censorship policies will have the capacity to regulate Internet in any substantial way. In 2000, President Bill Clinton described China's attempts to regulate Internet as: "sort of like trying to nail Jell-O to the wall" (The Economist, 2006). Academics such as Ashley Esarey and Xiao Qiang (2008) argue that even though some regime critical opinions might be successfully censored, skilled Chinese Internet users will still be able to criticize the country's leadership by using subtle communication such as satire: "Chinese are speaking truth to each other, and by doing so in a widely accessible manner, are speaking truth to power" (p.753). The New York Times columnist Nicholas D. Kristof (2005) occupies a particularly radical position by stating that: "anybody who loves China as I do would be hostile to an empty Mao suit like Mr. Hu. But it's the Chinese leadership itself that is digging the Communist Party's grave, by giving the Chinese people broadband".

\subsection{Skeptics}

In contrast to the aforementioned school, the skeptics question whether the Internet use will be able to change the nature of China's one-party system in any substantial way. Larry Diamond, for example, gives some credit to this school of thought by stating that: "technology is merely a tool, open to both noble and nefarious purposes" (2010, p.71). James Leibold (2011) argues that political Internet discussions are neglected by most Chinese and consequently are unable to threaten the party state (p. 1023). There are also skeptics who focus on how Chinese authorities actively use Internet in order to spread opinions supporting the party. Although not a skeptic, David Bandurski has described how the CCP employs young Internet users, the so-called 50-cent party, with the mission to express and defend the party line in microblog discussions and in debate forums (2008). Referring to the 50-centers, the skeptic Evegeny Morozov states that this kind of active propaganda shows that: "authoritarian governments have proved remarkably adept at shaping the direction, if not always the outcome, of most sensitive online conversations" ((2011, p.135). Also Anne-Marie Brady (2001) stresses the importance of the CCP's active propaganda. She argues that the combination of new and innovative propaganda methods might give CCP the possibility to stay in power for a long time: "The CCP has shown itself adept at adapting to change and challenging circumstances, absorbing new approaches and taking on new directions when necessary. This chameleon-like quality is one of the CCP's successes as one of the few remaining communist governments in the world, and it bodes well for its bid to stay in power indefinitely" (p.578).

\subsection{Reserved Optimists}

Some scholars argue that increasing Internet use do not by default forebode an end the one-party system. However, as witnessed by the social protest movements of the Arab Spring, digital communications and social media use definitely strengthen activists' possibilities to influence China's politics, making any kind of predictions difficult. According to some observers, the Chinese seem to authorities tolerate activists who use the Internet to criticize the CCP's policies but refrain from questioning the one-party system. Rebecca Mackinnon 
(2011) uses the concept "network authoritarianism" to describe the CCP's attitude towards the expressions of opinions on Internet: "When an authoritarian regime embraces and adjusts to the inevitable changes brought by digital communications, the result is what I call 'networked authoritarianism'. In the networked authoritarian state, the single ruling party remains in control while a wide range of conversations about the country's problems nonetheless occur on websites and social-networking services" (p.33). Yongnian Zheng (2012) argues that Internet activists who attack the party's leadership are suppressed, whereas activists who criticize certain policies without challenging the party's core principles can be seen as helping hands to reformists inside the party (p. 164-165). Johan Lagerkvist (2010) describes the Chinese state and civil society as mutually embedded. This interdependence enables the state to limit the civil society's potential to grow into an oppositional force. On the other hand, the mutual embeddedness also enables civil society to influence the state, for instance by the use of netizen activism (p. 267-271). A number of scholars even stress that some ideological debate are allowed inside the party system. Yongnian Zheng, Gang Chen \& Liang Fook Lye (2012) show that nationalists as well as both left- and right-wingers often express their views on Internet, without necessarily threaten the party's leadership. Activists supporting the "left-winged" Chongqing model associated with the city's fallen party boss Bo Xilai and the "liberal" Guangdong model associated with the province party secretary Wang Yang are for instance often expressing their views on Internet (Cartier and Tomba, 2012). The arguments of scholars who can be described as reserved optimists resembles the argument by Lagerkvist (2012), who in his investigation of the uprising in the village of Wukan. Lagerkvist argues that the successful management of the Wukan uprising was a result of the non-system critical nature of the Wukan rioters' demands (p. 356). Johan Lagerkvist labels this kind of in-system critique loyal dissent. This paper builds on the concept of loyal dissent to describe the kind of political arguments, which criticize the party and its policies without directly challenging the existing arrangements of the one-party system.

\section{Method}

In this study we analyze 200 microblog tweets, which were selected during the spring of 2012. All of these tweets discuss political issues that are considered sensitive in the Chinese context. During 2012 a number of events led to fierce political discussions in the Chinese blogosphere. One of the most notable was the fierce protest against illegal selling of communal land by corrupt village leaders in the Wukan, a village located in the Southern Province of Guangdong. The former Party Secretary of Guangdong, Wang Yang, managed to solve the standoff by agreeing to the demands made by the villagers, including the holding of democratic village committee elections, in accordance with Chinese organic law. The peaceful resolution of this local conflict caused many commentators inside and outside China to positively discuss the advantages and disadvantages of more openness and democracy in China. In contrast to Wukan, however, the authorities of Zhejiang province decided to crush a similar social protest, also motivated by a large-scale land grab in the village of Panhe. The less peaceful outcome of the Panhe event led many weibo commentators to more pessimistically question and analyze the behavior of Chinese local governments. Another event concerned the death sentence against a former businesswoman, $\mathrm{Wu}$ Ying, around whom a debate about China's legal system and the legitimacy of death penalty was ignited online. Other topics of concern to Internet users during 2012 related to poisoned food and food security, and calls for the introduction of more reform policies in the run-up to the 5th Plenary Session of the 11th National People's Congress (NPC). Particularly sensitive at the time of the NPC, however, was the flight of Chongqing's police chief Wang Lijun, who took temporary refuge at the US Consulate in Chengdu. The turmoil that followed from Wang's subsequent overturn to the authorities and his revelations about his former political boss Bo Xilai, eventually led to the fall of this left-leaning Party Secretary of Chongqing. The incident led to an avalanche of citizen commenting on the issue of the state's reporting of news and the behavior of high-level Party officials. Common for all the above-mentioned events was that the CCP's management of these crises was critically questioned from various perspectives. Arguably, one inherent advantage of this is that these events can be seen as most-likely cases to reveal radical opinions on CCP among Internet users. A second advantage of our selection of cases is the relatively long time-period over which tweets are analyzed, as well as the variety of sociopolitical phenomena that these incidents relate to. These advantages make for strong generalizability and validity.

The tweets included in the study are systematically selected, i.e. they are not random samples. The tweets have been collected continuously from one of China's largest microblog websites Sina Weibo (新浪微博) during the spring of 2012. The investigated tweets were collected using keywords associated to political topics such as Wukan(乌坎), Panhe(泮河) and Wu Ying (吴英). Among tweets containing these keywords only the most popular or "hot" remen(热门) tweets have been included in the material. Remen is one of Sina Weibo's functions and enables the user to find tweets frequently retweeted and commented on. Given the high frequency of 
retweets and commentaries, text messages selected by this function should have a potentially high impact on microblog users. Furthermore, the material has been collected from those tweets that were accessible to all users during the period our investigation, which is not the same as all posted Sina Weibo tweets during this time .Since censors continuously delete critical weibo messages, this study cannot give a comprehensive picture of all the different views among Chinese Internet users. However, the purpose of this paper is not to clarify which opinions weibo users actually have, beyond censorship, but to understand the political impact of China's social media - post-censorship. It is obvious that accessible and actually existing tweets influence weibo users more than deleted tweets, which are read and forwarded by fewer people.

\section{Analysis}

As a first step, the tweets are sorted into five overall categories depending on how the CCP's management of the discussed political issues are described in the text messages (Note 2): criticism of the political system, loyal dissent, enigmatic criticism, support of the CCP and no criticism. In table I tweets have been classified in the following manner:

- Tweets clearly criticizing the party's leadership and the one party system are coded as criticism of the political system.

- Tweets criticizing CCP's behavior or policies without questioning the party's hold on power are given the coding loyal dissent.

- Tweets which cloak criticism in an enigmatic language characterized by sarcasm, historical references and poetry-like expressions, which maybe written with the purpose to mislead censors are coded as enigmatic criticism.

- Tweets that express any kind of support for CCP or some parts of the party are coded as support of the $C C P$. This category might include tweets written by " 50 cents" employed by the party.

- The no criticism category consists of text messages, which do not deliver any criticism against the CCP. The category includes informative messages witch describe events from a neutral perspective, jokes without political content and messages which discuss non-political topics but still includes keywords associated with political issues.

Table 1. Overall categorizationofcriticism in populartweetsduring Spring 2012

\begin{tabular}{llllll}
\hline & $\begin{array}{l}\text { criticism of the political } \\
\text { system }\end{array}$ & $\begin{array}{l}\text { loyal } \\
\text { dissent }\end{array}$ & $\begin{array}{l}\text { enigmatic } \\
\text { criticism }\end{array}$ & $\begin{array}{l}\text { supportive of the } \\
\text { CCP }\end{array}$ & $\begin{array}{l}\text { no } \\
\text { criticism }\end{array}$ \\
\hline Frequency & 6 & 85 & 20 & 32 & 57 \\
Percentage & $3 \%$ & $42,5 \%$ & $10 \%$ & $16 \%$ & $28,5 \%$ \\
\hline
\end{tabular}

Source: Sina Weibo February 11 - June 4, 2012.

According to Table I the politically interested weibo users seem to focus on tweets evaluating the ruling party. The table clarifies that most of the investigated tweets express opinions on the CCP's role in managing the concerned political issues (about 70 percent of the tweets). The table also clarifies a huge proportion of the tweets seems to contain loyal dissent against the CCP. However, before any conclusions are made, internal differences in the categories have to be investigated more carefully.

\subsection{Criticism of the Political System}

Among the text messages included in the study very few contain opinions that are very radical. Only 3 percent of the postings criticize the party's hold on power. This result is not surprising given that the authorities probably demanded Sina Weibo's in-house censors to delete many tweets that were openly critical of China's political system. Nevertheless, some text messages of such a critical nature are accessible, such as this tweet posted March 30: "The realization of democracy in China is the historical mission of our generation, all people have to give their life for this mission. If the next generation has to realize democracy it would be a shame for our generation" (for the original text see Note 3). Even though the CCP states that China already displays many democratic characteristics it is quite clear that the writer views democracy as non-existing in China. The writer does not seem to support the present political system since s/he argues that the lack of democratic progress in today's China is a shame. Other tweets that can be described as critical of the political system, since they call for the use of violence, indicate that a violent revolution might be legitimate. One tweet posted on April 18 can serve as an example: "From now on, factory workers and villagers with requests, shall not hesitate to pick up weapons 
and unite for the sake of self-defense. They shall not tolerate any level of the government's inhuman and immoral violations of rights and bad conduct" (Note 4). In this case the writer advocates the use of political violence and justifies this by rebuking the government's "immoral" behavior. Thus it seems like the writer rejects the feasibility to work for redress within the present political system, and to contrary advocates political rebellion against the ruling Party.

\subsection{Enigmatic Criticism}

As Esarey and Xiao (2011) points out, a lot of fierce online criticism against the party is written in an enigmatic language. Consequently it is important to analyze this kind of tweets more carefully, as they might contain hidden criticism against the political system and the CCP. In table II tweets containing enigmatic criticism are divided into two subcategories, depending on whether they seem to oppose the one-party system or not.

Table 2. Criticism against the CCP in enigmatic tweets

\begin{tabular}{lll}
\hline & enigmatic system criticism & enigmatic loyal dissent \\
\hline Frequency & 5 & 15 \\
Percentage & $25 \%$ & $75 \%$ \\
\hline
\end{tabular}

Source: Sina Weibo February 11 - June 4, 2012.

There is reason to believe that more tweets can be described as critical against the political system if enigmatic language is analyzed carefully. Take a tweet posted on April 2 for example. The writer criticizes the weibo users for expending too much energy in discussing celebrities such as the well-known author, race car driver and blogger Han Han while most users ignore politics: "When the villagers of Wukan elect a village committee, they are talking about Han Han. When the people of the other shore vote for "president" (Note 5), they are talking about Han Han. When Hongkong's administrative region experiences a crisis of confidence, they are talking about Han Han. Even when the people of Myanmar vote in parliamentary elections and Aung San Suu Kyi enters the regime, they are still talking about Han Han" (Note 6). Expressions like this do not directly criticize China's political system. However, it seems like the writer wants the weibo users to focus more on democracy and free elections instead of entertainment and celebrities. This does not mean advocating a different political system, but it calls for more overt and open political discussion. The following tweet posted on April 25 is an example of a message hostile toward the regime, albeit cloaked in obscure language: "This oligarchical system use dissatisfaction with corrupt dictatorship to crate fake democracy. However, the election results are ignored. The truth is concealed and the people's limited resources get lost in a black hole. People's intellectual awakening will encourage them to oppose this system. Wukan-style resistance will be everywhere" (Note 7). The writer describes Chinese elections as hypocritical and hopes that the people will rise up. Given the context, the writer would probably favor a system with "real elections," thus calling for a change of political system.

Even though some of the enigmatic messages can be described as critical against the political system, most of them are better described as evidence of loyal dissent. In one tweet published June 11, a writer describes a satiric marriage ordinance probably with the purpose to criticize the state of food safety in China: "Priest: do you accept this man as your husband, to join him drinking melamine milk and gelatin yogurt? Join him to eat lean pork, water injected beef and poisonous cabbage until death do you apart?"(Note 8). In another tweet discussing the same topic a writer use enigmatic poetry-like language in order to criticize the possibilities for realizing food security: "Food security will be realized if corrupted officials not were corrupted, if the sun rises up in the west, if prostitutes were virgins, if nuns went secular, if Qingdao did not plant trees, if Lei Feng become an evildoer, if Wukan become the capital" (Note 9).

\subsection{Support of the CCP}

Tweets that at first glance seem to be supportive of the CCP needs to be investigated more carefully too. Many of these tweets are in fact only supporting one of the CCP's ostensibly most ideological factions: either the liberal faction that have popularly associated with the so-called Guangdong model of economic liberalism, or the left-wing faction associated with the so-called Chongqing model, that during the rule of its Party Secretary leaned toward old-style Maoist policy planning and nostalgia. Furthermore, some tweets containing loyal dissent against the CCP are in fact criticizing one of these two factions. Even though it is doubtful if these two factions actually exists inside the Party, many weibo users do refer to Guangdong and Chongqing when they argue for liberal or left wing policies. In table III all tweets supporting the CCP and/or supporting or criticizing one of the 
two factions are separated in three subcategories: support of the CCP as a whole, support of the CCP's liberal faction and support of the CCP's left-wing faction.

Table 3. Tweets expressing support of the $\mathrm{CCP}$ or factions within the party

\begin{tabular}{llll}
\hline & $\begin{array}{l}\text { support of the CCP as a } \\
\text { whole }\end{array}$ & $\begin{array}{l}\text { support of the CCP's liberal } \\
\text { faction }\end{array}$ & $\begin{array}{l}\text { support of the CCP's left-wing } \\
\text { faction }\end{array}$ \\
\hline Frequency & 17 & 25 & 3 \\
Percentage & $37,8 \%$ & $55,5 \%$ & $6,7 \%$ \\
\hline
\end{tabular}

Source: Sina Weibo February 11 - June 4, 2012.

Given the above division, a large proportion of tweets that show some kind of support of the CCP actually support the Party's more liberal wing. Some of these tweets indicate support for Wukan's new Party Secretary Lin Zulan who quite often was interpreted to be a different kind of liberal leader at the grassroots level. The following tweet posted on April 13 is a good example: "Lin Zulan: I want to be a naked gold fish in a glass bowl that can be seen by everyone through the transparent water. In this way I can supervise myself and let other people supervise the entire political process!" (Note 10). In other tweets of a liberal inclination, some writers clearly support the policies of Guangdong Province and contrast them to the policies in the left-wing megacity of Chongqing, as for instance this tweet posted February 15 showcases: "Firstly, the 'Wukan incident' was a serious crisis but Wang Yang's way of solving the crisis by using the 'Guangdong model' has created a breakthrough. By using local democracy he has been able to lead a citizens' social revolution. Secondly, to sing red and strike black, the pseudonym for the so called 'Chongqing model' is now collapsing after the Wang Lijun incident occurred" (Note 11). In contrast to these tweets there are a number of frequently retweeted messages that criticize China's liberal faction and support the Party's left wing. One example is the following tweet that criticizes privatization: "Privatization of state companies is in reality a legalization of theft. Financial liberalization means legalization of fraud. Give Wu Ying the right to fraud! Give Gu Chujun the right to fraud and steal state companies! These people are fraudsters and thieves. This is the core of China's liberal faction and the country's plundering capital groups" (Note 12). In another tweet posted on May 16, the writer attacks the Guangdong model: "The so-called Guangdong model is the barbarian market economy's model, it is an exploiting and suppressing model hitting the bone and sucking the marrow" (Note 13).

Tweets that praise the handling of the Wukan incident do not necessarily have to be interpreted as supportive of the CCP's liberal faction. Some writers might praise the management of Wukan in order to show support of the CCP as a whole. There is, for instance, reason to believe that the following tweet posted on February 14 should be interpreted as containing more general support of the CCP: "The Guangdong officials were showing an ideal attitude. This attitude could also be seen as a sense of balance. Politics is sometimes easy; actors have to return to consensus" (Note 14). In this tweet the writer plays down the groundbreaking and democratic aspects of Wukan that were noted by some users, and instead points to the normalcy in how the crisis was handled, as well as the importance of consensus as an alternative to conflict. These opinions resemble the CCP's Party line attitude towards the Wukan-incident. Other tweets can be said to support the Party by opposing rumors opposing the Party line. In a tweet posted on February 14, long before Chongqing Party Secretary Bo Xilai's fall, a writer questioned the rumors about a conflict between Wang Lijun and Bo Xilai: "I have to raise my own opinions regarding the WLJ question: 1. People who say there is an underlying story are playing with the devil. Regarding the material on Internet smearing Wang Lijun and Bo Xilai, even arguing that Bo tried to kill Wang etcetera, I can tell you this is all nonsense" (Note 15). In a similar tweet posted on February 16, the writer argues that "lies" about the riot in Panhe are in fact written by "extremist Hitler-like people" (Note 16).

Should tweets supporting one of the CCP's two main ideological factions be interpreted as supportive for the central Party line or as loyal dissent against the Party? Given the layout of most of these tweets it can be argued that the writers support or criticize one of the two ideological factions in order to impact on and seek to alter the policies of the Chinese Communist Party. Writers praising the democratic breakthrough in Wukan often argue that more democratic and transparent governance should be practiced also in other parts of China. Tweets criticizing the market economy can on the other hand be seen as critical to the highest Party leadership's, in general, market friendly policies. Consequently, underlying these kinds of ideological expression is often criticism against the general state of Chinese politics. Nevertheless, very few of the tweets supporting the Guangdong or the Chongqing models are criticizing the Party's hold on power. Consequently, liberal or leftwing 
expressions should rather be described as loyal dissent than criticism against the political system or support of the Chinese Communist Party.

\subsection{Loyal Dissent}

Even if tweets that support various factions inside the Party would not be included in this study, expressions of loyal dissent are obviously very widespread among popular, uncensored, political tweets. All these tweets may be characterized by their critique against the policies of the CCP - without ever directly questioning the one-Party system and its foundations. Indeed, many tweets of this study express criticism against the Party's policy. For instance, the following tweet posted on March 29 attacks the National Development and Reform Commission (NDRC) but it does not criticize the Party as a whole: "Is the NDRC really crazy? The price of electricity will once again increase, the price of natural gas will be reformed and the price of oil is not high enough, even though it has been raised fifteen times since 2004?" (Note 17). In another tweet the practice of the death sentence is criticized: "The Supreme Court did not approve Wu Ying's death sentence. This is a victory for China's Internet opinion. The opinion on the Internet is not always accurate, but China has yet again to make its homework and put more energy in respecting popular opinion. I am still saying: no murder, no death penalty, this applies for everyone." (Note 18) Furthermore, many writers express criticism against the CCP by attacking the behavior of Party officials. In tweets that discuss the National People's Congress (NPC), several writers raged against delegates who were falling asleep during meetings. A tweet posted on March 8 can serve as an example: "Those who have sucked so much blood, sweat and money from the people go to the Great Hall of the People in order to have their beauty sleep. Who have elected these delegates? Go home and sleep!'(Note 19). Criticism against the implementation of the Party's policies is another type of common loyal dissent. In a tweet posted on February 16, the writer explicitly targets the security forces in the rioting village of Panhe: "In the last days, foreign journalists who have investigated the land dispute in the village of Panhe, Zhejiang province, have continuously been tracked by the police and other groups of unidentified people. Many journalists have been beaten and equipment has been destroyed. Why are these governmental thugs tolerated?"(Note 20). Finally, a lot of tweets criticize the veracity of governmental information. In a tweet posted April 13 the state controlled media's coverage of the Bo Xilai incident is criticized: "China's media world (CCTV, People's Daily, Global Times) has to learn a lesson. The difference between normal news and breaking news has to be discussed. Normal news is news fabricated by the government. Breaking news is civil rumors edited by the government" (Note 21).

Even though there are internal differences between the tweets that express loyal dissent against the CCP, there are also important similarities. None of these tweets directly challenges the one Party-system. Instead they criticize actions, policies and behavior of the Party and/or subgroups inside the political system. Many tweets can thus be interpreted as calls for change in the Party's behavior or policies. These important similarities also matter for enigmatic loyal dissent and to some extent also for tweets that support or criticize factions inside the Party. It can be argued that all these three categories can be coded as containing loyal dissent since they, in fact, criticize the Communist Party's present policies and behavior while they do not call for an end of the one Party system. Interpreted in this way, a great majority of the investigated tweets are displaying loyal dissent as seen in Table 4:

Table 4. Concluding criteria of criticism in popular tweets during Spring 2012

\begin{tabular}{lllll}
\hline & criticism of the political system & support of the CCP as a whole & loyal dissent & no criticism \\
\hline Frequency & 11 & 17 & 115 & 57 \\
Percentage & $5,5 \%$ & $8,5 \%$ & $57,5 \%$ & $28,5 \%$ \\
\hline
\end{tabular}

Source: Sina Weibo February 11 - June 4, 2012.

\section{Conclusion}

The findings of this study contribute to the debate on how increasing Internet usage impact on Chinese politics. Optimists such as Kristof and Yang have stated that the Internet will eventually lead to a democratic evolution in China. However when viewing one particular form of online expression, weibo, and given the content in popular and accessible weibo postings/tweets that discuss sensitive political issues, only a very small proportion of the tweets call for an end to China's one-Party system. As stated by Esarey and Xiao, some weibo users hide system criticism in enigmatic expressions. Yet this kind of euphemistic criticism against the political system is 
uncommon in popular tweets. The low frequency of tweets containing direct criticism of the political system is of course likely to be a result of censorship practices by Sina Weibo and self-censorship practices by individual users. Yet, the low support for an end of one Party rule among the remaining weibo postings, and the many expressions belonging to the category of loyal dissent cannot all be the product of government or corporate censors. In either case, our findings do not indicate that the Chinese blogosphere and micro-blogosphere will be a catalyst for democratization in the near future.

Even though system criticism is rare, the same goes for support for the CCP as a whole. Few weibo users express support for the Party's behavior in discussions on sensitive issues. Those that express support are mainly praising the Party leaders in Guangdong or of Wukan's ad hoc and later new village committee, not the central leadership. These findings also indicate that the CCP's active propaganda undertaken by the army of so-called 50-centers, do not appear successful in posting powerful messages that attract serious attention. It is of course possible that netizens employed by the CCP post many Party friendly tweets, but if this is the case Chinese Internet users do not heed the content of these text messages, do not reply to them, or retweet them.

On the other hand, our study gives plenty of support to reserved skeptics who stress the Internet's potential to catalyze loyal dissent against the CCP. Half of the tweets investigated seem to contain features of loyal dissent against the Party. If tweets supporting or criticizing the Party's liberal and/or left wing fractions are included in this category, almost 60 percent of the tweets include loyal dissent. That is considerably more than the tweets including criticism against the political system or support of the CCP. From the perspective of formation of public opinion, the blogosphere ought to be viewed as a more critical forum than the mainstream Chinese media and consequently has the potential to foster a generation of more critical Chinese citizens, who can reflect critical views much easier than previous generations. Still, this does not indicate that weibo users will ask for an end of the one party system in the immediate future.

\section{References}

Bandurski, D. (2008). China's Guerrilla War for the Web.Far Eastern Economic Review, 171(6), 41-44.

Brady, A. (2001). Regimenting the Public Mind: The Modernization of Propaganda in the PRC. International Journal, 57(4), 563-578. http://dx.doi.org/10.2307/40203692

Carolyn, C., \& Tomba, L. (2012). Chapter 2: Symbolic Cities and the 'Cake Debate', Australian Center on China in the World.

http://www.thechinastory.org/yearbooks/yearbook-2012/chapter-2-symbolic-cities-and-the-cake-debate/, (Last accessed 2012, December 04).

Esarey, A., \& Xiao, Q. (2011). Digital Communication and Political Change in China. International Journal of Communication, 5, 298-319.

Esarey, A., \& Xiao, Q. (2008). Political Expression in the Chinese Blogosphere: Below the Radar. Asian Survey, 48(5), 752-772. http://dx.doi.org/10.1525/AS.2008.48.5.752

Diamond, L. (2010). Liberation Technology, Journal of Democracy, 21(3), 69-83.

Kristof, N. (2005, May 24). Death by a Thousand Blogs. The New York Times. http://www.nytimes.com/2005/05/24/opinion/24kristoff.html, (Last accessed 2012, October 09).

Lagerkvist, J. (2010). After the Internet, Before Democracy: Competing Norms in Chinese Media and Society. Bern, Peter Lang.

Lagerkvist, J. (2012). The WukanUprising and Chinese State-SocietyRelations: Toward "Shadow Civil Society"? International of Journal China $\quad$ Studies, $345-361$. http://cmsad.um.edu.my/images/ics/IJCSV3N3/lagerkvist.pdf, (Last accessed 2013, April 27).

Leibold, J. (2011). Blogging Alone: China, the Internet, and the Democratic Illusion? The Journal of Asian Studies, 70(4), 1023-1041. http://dx.doi.org/10.1017/S0021911811001550

Mackinnon, R. (2011). China's "Networked Authoritarianism". Journal of Democracy, 22(2), 32-46. http://dx.doi.org/10.1353/jod.2011.0033

Morozov, E. (2009, March 29). Propaganda.com, The New York Times, http://www.nytimes.com/2009/03/30/opinion/30iht-edmorozov.html?_r=0, (Last accessed 2012, October 09).

Morozov, E. (2011). The Net Delusion. New York, Public Affairs. 
Schola, N. (2010, October 12). Quote of the Day: God's Gift to China. Personal Democracy Media, http://techpresident.com/blog-entry/quote-day-gods-gift-china, (Last accessed 2013, March 11).

The Economist. (2006, April 27). The party, the people and the power of cyber-talk. The Economist. http://www.economist.com/node/6850080?story_id=6850080, (Last accessed 2013, March 11).

Wang, C. (2010). Guanyu Woguo Hulianwang Fazhan he Guanli, [Regardingmy Country's development and administration of Internet]. PRC Central Government Official Web Portal, http://www.gov.cn/gzdt/201005/05/content_1599822.htm>, (Last accessed 2010, July 04).

Xiao, Q. (2004, November 24). The 'blog' revolution sweeps across China. New Scientist. http://www.newscientist.com/article/dn6707-the-blog-revolution-sweeps-across-china.html?full=true, (Last accessed 2013, March 11).

Xiao, Q. (2011). The Rise of Online Public Opinion and its Political Impact. In Susan, S (Ed), Changing Media, Changing China (pp. 202-224). Oxford, Oxford University Press.

Yang, G. (2009). The Power of the Internet in China. New York, Colombia University Press.

Zheng, Y., Chen, G., \& Lye, L. (2012). China's Politics: Preparing for Leadership Reshuffling and Maintaining Status Quo. East Asian Policy, 4(1), 5-13. http://dx.doi.org/10.1142/S1793930512000013

Zheng, Y. (2008). Technological Empowerment, Stanford, Stanford University Press.

\section{Notes}

1. Scholars' labeling of these two concepts varies. Lagerkvist terms the division as "two grand narratives" (Lagerkvist, 2010, p. 16). MacKinnon (2011) uses the concept "Iron Curtain 2.0" to label views stating that Internet will tear down dictatorships but oppose this position by stating that authoritarian regimes are able to learn how to manage Internet, a phenomenon she calls "networked authoritarianism" (p. 33-34).

2. Given the party-state nature of China's political system, criticism against the authorities and the state is also seen as criticism against the CCP.

3. 中国实现民主是我们这一代人的历史使命，每个人都应当为之献身。如果中国的民主需要下一代 去实现，就是我们这一代人的耻辱, posted 2012.03.30.

4. 从现在起, 有条件的厂企工人, 乡镇村民都应该毫不犹豫, 操起一切可以自卫的武器, 奋起团结 自卫，绝不容忍，姑息，纵容各级政府反人类道义的侵权恶行, posted 2012.04.18.

5. The writer probably aims at the presidential elections in Taiwan.

6. 乌坎一人一票选举村委会, 他们在说韩寒; 对岸一人一票选举 "总统 ", 他们在说韩寒: 香港特 首诚信危机, 唐梁混战, 他们在说韩寒; 连缅甸都一人一票国会补选, 昂山素季进入政权了, 他 们还在说韩寒, posted 2012.04.02.

7. 有这样一种顶层设计, 利用对腐败专制不满盅惑虚假民主, 真选却去回避, 采取坑蒙欺诈手段涸 泽而渔坑民，不顾人多资源有限助力嗜血鲸吞。民智觉醒必将对此阻击，遍地乌坎抗争，posted 2012.04.25.

8. 神父: 你是否愿意这个男子成为你的丈夫, 陪他吃三聚氭胺奶、明胶酸奶、瘦肉精猪肉、注水牛 肉、毒白菜直至生命尽头?, posted2012.06.11.

9. 食品安全: 除非贪官不贪污, 除非太阳西边出, 除非小姐都是处, 除非尼姑都还俗, 除非青岛不植 树, 除非雷锋当夕徒, 除非马坎成首都, posted 2012.05.04.

10. 林祖裣: 我要做一条在鱼缸里赤裸裸的金鱼, 在透明的水和鱼缸里供大家观赏, 这样可以监督自 已和让他人监督整个问题处理过程! , posted 2012.04.13.

11. 一 "乌坎事件 "本是一次严重危机, 但汪洋的处理反令 "广东模式 " 取得突破、地方民主选举破 冰、公民社会之变革取向得以确立; 二呾红打黑、剑走偏锋的 " 重庆模式 "随着王事件正陷于崩 溃, posted 2012.02.15.

12. 国企私有化, 实际上就是要求盗突合法化。金融自由化, 就是要求行骗合法化。给吴英行骗的自 由! 给顾维军行骗加盗铊国企的自由! 这就是骗子、小偷、铵贼集团一中国自由派资本集团或 掠夺投机资本集团的心声。, posted 2012.03.21.

13. 所谓广东模式就是野蛮的市场经济模式、敲骨吸髓式的剥削压樵模式, posted 2012.05.16.

14. 广东官方体现了理性的精神。理性也可理解为平常心。政治有时很简单, 就是回归常识, posted 2012.02.14.

15. 关于 WLJ 的问题我来谈谈自己几点看法: 1, 现在谁说有内幕都是装神弄鬼, 网上那些王有薄 的黑材料, 薄整王甚至暗杀等等, 这我可以告诉你肯定绝对是无稽之谈。, posted 2012.02.14.

16. 有极端利益欲望“希特勒”的人, posted 2012.02.16. 
17. 发改委真的疯了? 电价要实行梯次电价, 天然气价格要改革, 油价没涨够, 说是从 2004 年以来涨价十五次, posted 2012.03.29.

18. 最高法院未核准吴英死刑, 这是中国互联网舆论的一次胜利。舆论展示力量的机缘并非 总是很准确，但对啭论给予更多尊重是中国必须做的补课。我还是那句话: 无命案，不 死刑。这适用于所有人。, posted 2012.04.20.

19. 糟蹋人民那么多血汗钱, 他们就去人民大会堂酣睡! 这是谁选的代表? 领回家睡去! , posted2012.03.08.

20. 前往浙江泮河采访当地土地纠纷的外媒记者近两天不断遭到警察和不明身份人员的跟踪, 多名记 者被打伤，设备被损坏，可为何这些暴徒官方视而不见，posted2012.02.16.

21. 给中国新闻界（CCTV人民日报环球时报）上个课，讲一讲在中国什么叫一般新闻和重大新闻。 恩!一般新闻就是官方自己编造的新闻; 重大新闻就是官方采编的民间谣言。, posted 2012.04.13.

\section{(cc) $\mathrm{BY}$}

This work is licensed under a Creative Commons Attribution 3.0 License. 